\title{
HUBUNGAN GAYA BELAJAR DENGAN HASIL BELAJAR SISWA PADA PEMBELAJARAN BIOLOGI KELAS X SMAN 2 SUNGAI TARAB KABUPATEN TANAH DATAR
}

\author{
Yen Chania, M. Haviz, Dewi Sasmita \\ Jurusan Tadris Biologi Fakultas Tarbiyah dan Ilmu Keguruan IAIN Batusangkar \\ Jalan Sudirman No. 137 Kubu Rajo Limokaum Batusangkar. \\ Email:mhaviz@iainbatusangkar.ac.id
}

\begin{abstract}
The purpose of this study was to determine whether there is a relationship of learning styles to student learning outcomes in learning biology. The strength of the relationship can be seen in the interpretation of the correlation table. This research is ex post facto with research subjects are students of class X SMAN 2 Sungaitarab the 2015/2016 academic year are 71 people with the sampling technique used was random sampling with an error rate of 5\%. Data collection method for variable learning style is by questionnaire, while studying biology outcome variables using vocational school documentation data analysis technique used is the product moment correlation with the level of significance of the analysis results is set at $5 \%$. The results showed that there are no significant and positive relationship between learning styles to student learning outcomes in learning biology, this is evidenced by rhitung $(0.089)<\mathrm{rtabel}(0,235)$, the Ha Ho is rejected and accepted. Based on the results of the study showed no significant positive relationship between the three variables of learning styles to student learning outcomes in the subjects of biology, it is thus test this hypothesis does not support the research.
\end{abstract}

Key words: learning styles, learning outcomes, biology

\section{PENDAHULUAN}

Pembelajaran IPA bertujuan agar siswa mampu menguasai konsep-konsep IPA dan saling keterkaitannya, serta mampu menggunakan metode ilmiah untuk memecahkan masalah yang dihadapinya. Salah satu pelajaran yang mempersiapkan siswa untuk mampu hidup dan mampu menyumbangkan sesuatu pada kehidupan adalah Ilmu Pengetahuan Alam. Ilmu Pengetahuan Alam termasuk bagian dari sains baik dalam arti luas maupun sempit merupakan bagian dari kehidupan manusia. Manusia dalam aktifitas sehari-hari selalu bergelut dengan dunia sains baik dari yang sederhana hingga yang sangat kompleks sifatnya. Menyadari betapa pentingnya pendidikan sains, telah banyak upaya dilakukan untuk meningkatkan kualitas pembelajaran sains di sekolah diantaranya penyempurnaan kurikulum peningkatan profesionalisme guru, buku-buku penunjang, peralatan laboratorium, media pembelajaran, pengembangan strategi yang lebih relavan dan efektif dalam mencapai tujuan belajar sains, dan sebagainya.

Hakikat Biologi tidak hanya berupa teori, hafalan dan pemahaman akan konsep saja, tetapi juga berupa proses penerapan dan bahkan penemuan, maka dalam pembelajarannya harus melibatkan siswa secara aktif untuk berinteraksi dengan objek konkret (Wulandari, $2007: 3$ ).

Namun, tidak semua siswa yang terlibat aktif dalam pembelajaran, karna ada sebagaian mereka yang lebih suka belajar mendengarkan guru nya berceramah saja. Karna setiap siswa 
memiliki gaya belajar yang berbeda-beda. Untuk itu, siswa harus mengenali bagaimana gaya belajar nya sendiri agar mudah untuk menerima pembelajaran. Selain itu guru juga harus mengenali gaya belajar siswanya juga agar nantinya guru bisa mempersiapkan strategi yang cocok untuk diajarkan khususnya pada mata pelajaran biologi agar hasil belajar siswa bisa maksimal.

Dilihat dari data siswa di SMAN 2 Sungai Tarab masih banyak yang memperoleh nilai rendah mata pelajaran Biologi, yang disebabkan oleh berbagai faktor, baik faktor internal maupun faktor eksternal yang mempengaruhi hasil belajar Pendidikan Kewarganegaraan.

Salah satu karakteristik siswa yang berpengaruh terhadap hasil belajar adalah gaya belajar. Gaya belajar merupakan suatu tindakan yang dirasakan menarik oleh siswa dalam melakukan aktivitas belajar, baik ketika sedang sendiri atau dalam kelompok belajar bersamasama teman sekolah (Sopiatin dan Sahrani, 2011 : 36). Gaya belajar merupakan modalitas belajar yang sangat penting. Menurut Hasrul (2009 : 2) "Gaya belajar merupakan suatu kombinasi dari bagaimana seseorang menyerap dan kemudian mengatur serta mengolah informasi. Gaya belajar bukan hanya berupa aspek ketika menghadapi informasi, melihat, mendengar, menulis dan berkata tetapi juga aspek pemrosesan informasi sekunsial, analitik, global atau otak kiri dan otak kanan. Aspek lain adalah ketika merespon sesuatu atas lingkungan belajar (diserap secara abstrak dan konkret)."

Gaya belajar merupakan bentuk dan cara belajar siswa yang paling disukai yang akan berbeda antara yang satu dengan yang lain, karna setiap individu mempunyai kegemaran dan keunikan sendiri-sendiri yang tidak akan sama dengan individu lain. Secara umum gaya belajar adalah cara yang lebih kita sukai dan membuat kita nyaman dalam melakukan kegiatan berpikir, memproses dan mengerti suatu informasi. Kemp dalam Liyusri dan Situmorang (2013 : 4) menyatakan bahwa gaya belajar adalah cara mengenali berbagai metode belajar yang disukai yang mungkin lebih efektif bagi siswa tersebut.
Gaya belajar mengacu kepada cara belajar yang lebih disukai pembelajar. Umumnya, dianggap bahwa gaya belajar seseorang berasall dari kepribadian, termasuk kemampuan kognitif dan psikologis latar belakang kehidupan, serta pengalaman pendidikan. Keanekaragaman Gaya belajar siswa perlu diketahui pada awal diterima pada suatu lembaga pendidikan yang akan ia jalani. Hal ini akan memudahkan bagi siswa untuk belajar maupun bagi seorang pengajar dalam proses pembelajaran. Siswa akan dapat belajar dengan baik dan hasil belajarnya baik, apabila ia mengerti gaya belajarnya. Hal tersebut memudahkan siswa dalam menerapkan pembelajaran dengan cepat dan tepat. Berarti berhasil atau tidaknya pencapaian tujuan pendidikan banyak tergantung pada bagaimana proses belajar yang dialami oleh siswa sebagai anak didik. Untuk itu siswa seharusnya bisa mengenali bagaimana gaya belajarnya agar bisa mencapai hasil yang maksimal dalam proses pembelajaran.

Dunn Opal dalam Sopiatin dan Sahrani (2011 : 4), menjelaskan bahwa dalam belajar, setiap individu memiliki kecendrungan kepada salah satu cara atau gaya tertentu. Kecendrungan seseorang ini disebut gaya belajar. Karakteristik siswa menggambarkan segi-segi latar belakang pengalaman siswa yang berpengaruh terhadap efektivitas proses belajarnya. Salah satu karakteristik siswa yang sebaiknya diperhatikan oleh guru dalam mendesain pembelajaran yang akan dikelolanya adalah gaya belajar. Gaya belajar mengacu pada cara belajar yang lebih disukai pembelajar. Umumnya, dianggap bahwa gaya belajar seseorang berasal dari variabel kepribadian, termasuk susunan kognitif dan psikologis latar belakang sosio cultural, dan pengalaman pendidikan.

Gaya belajar atau kadang dikatakan sebagai modalitas belajar atau tipe belajar ini dibagi menjadi 6 tipe belajar, yaitu visual, auditif, kinestetik, taktil, olfaktoris dan gustatif (Wiyani, 2013 : 24-26).

Selain gaya belajar diatas, terdapat juga gaya belajar berdasarkan modalitas indra. Pendekatan yang sering dan umum dipakai adalah gaya belajar berdasarkan modalitas indra 
ini, yaitu : gaya belajar visual, auditorial dan kinestetik (Irham dan Wiyani, 2014 : 105).

Gaya belajar tipe visual adalah gaya belajar dimana siswa cenderung belajar melalui apa yang mereka lihat. Bagi siswa yang bergaya belajar visual, mereka mengandalkan indera penglihatan (mata). Anak yang mempunyai gaya belajar visual, harus melihat bahasa tubuh dan ekspresi wajah gurunya secara langsung untuk mengerti materi pelajaran.

Ciri-ciri peserta didik yang tergolong tipe visual antara lain : (1) Mementingkan penampilan dalam berpakaian atau saat presentasi, (2) Lebih mudah mengingat mana yang dilihat daripada yang didengar, (3) Lebih suka membaca daripada dibacakan, (4) Dapat membaca dengan cepat, teliti, dan tekun, dan (5) Mengingat dengan asosiasi sosial (Wiyani, 2013: 24)

Ada beberapa strategi yang bisa digunakan untuk mempermudah proses belajar anak yang visual, yaitu (1) Gunakan materi visual, seperti gambar-gambar, diagram dan peta, (2) Gunakan warna untuk menghilite halhal penting, (3) Ajak anak untuk membaca buku-buku berilustrasi, (4) Gunakan multimedia (contohnya komputer dan video), dan (5) Ajak anak mencoba untuk mengilustrasikan ide-idenya kedalam gambar (Rahmawati, 2013 : 33)

Gaya belajar tipe Auditorial adalah gaya belajar dimana siswa cenderung belajar melalui apa yang mereka dengar. Mereka menikmati saat-saat mendengarkan apa yang disampaikan orang lain. Menurut Hasrul (2009: 4), Ciri-ciri anak yang belajar dengan gaya auditorial adalah sebagai berikut :

a) Berbicara kepada diri sendiri saat kerja, b) Mudah terganggu oleh keributan, c) Menggerakan bibir mereka dan mengucapkan tulisan dibuku ketika membaca, d) Senang membaca dengan keras dan mendengarkan, e) Dapat mengulangi kembali dan menirukan nada, birama, dan warna suara, f) Merasa kesulitan untu menulis, tetapi hebat dalam bercerita, g) Berbicara dengan irama yang terpolah, h) Biasanya suka musik daripada seni, i) Belajar dengan mendengarkan dan mengingat apa yang didiskusikan daripada yang dilihat, j) Suka berbicara, suka berdiskusi dan menjelaskan sesuatu panjang lebar, k) Mempunyai masalah dengan pekerjaanpekerjaan yang melibatkan visualisasi seperti memotong bagian-bagian hingga sesuai satu sama lain, 1) Lebih pandai mengeja dengan keras daripada menuliskannya, m) Lebih suka gurauan lisan daripada membaca komik.

Setelah memahami ciri-ciri gaya belajar auditorial diatas, maka untuk mempermudah proses belajar anak yang auditorial, ada beberapa strategi yang bisa digunakan, yaitu : (1) Ajak anak untuk ikut berpartisipasi dalam diskusi baik didalam kelas maupun didalam keluarga, (2) Dorong anak untuk membaca materi pelajaran dengan keras, (3) Gunakan musik untuk mengajarkan anak, (4) Diskusikan ide dengan anak secara verbal, dan (5) Biarkan anak merekam materi pelajarannya ke dalam kaset dan dorong dia untuk mendengarkannya sebelum tidur (Rahmawati, 2009 : 34).

Gaya belajar tipe Kinestetik adalah gaya belajar dimana siswa cenderung belajar melalui gerak dan sentuhan. Individu yang memiliki kecenderungan gaya belajar kinestetik akan belajar lebih baik apabila terlibat secara fisik dalam kegiatan langsung. Mereka akan belajar sangat baik apabila mereka dilibatkan secara fisik dalam pembelajaran. Mereka akan berhasil dalam belajar apabila mereka mendapat kesempatan untuk memanipulasi media untuk mempelajari informasi baru. Anak seperti ini sulit untuk duduk diam berjam-jam karena keinginan mereka untuk beraktifitas sangatlah kuat. Hasrul (2009 : 5), mengemukakan ciriciri atau karakteristik dari gaya belajar kinestetik ini adalah sebagai berikut : a) Berbicara dengan perlahan, b) Menanggapi perhatian fisik, c) Menyentuh orang untuk mendapatkan perhatian mereka, d) Berdiri dekat ketika berbicara dengan orang, e) Selalu berorientasi pada fisik dan banyak bergerak, f) Mempunyai perkembangan awal otot-otot yang besar, g) Belajar melalui memanipulasi dan peraktik, h) Menghafal dengan cara berjalan dan melihat, i) menggunakan jari sebagai penunjuk ketika membaca, j) Banyak menggunakan isyarat tubuh, k) Tidak dapat duduk diam untuk waktu lama, 1) Tidak dapat mengingat geografi, kecuali jika mereka memang telah pernah berada di tempat itu, m) 
Menggunakan kata-kata yang mengandung aksi, n) Menyukai buku-buku yang berorientasi pada plot - mereka mencerminkan aksi dengan gerakan tubuh saat membaca, o) Kemungkinan tulisannya jelek, p) Ingin melakukan segala sesuatu, q) Menyukai permainan yang menyibukkan.

Hasil belajar adalah kemampuankemampuan yang dimiliki siswa setelah ia menerima pengalaman belajarnya (Sudjana, 2005 : 22). Dalam proses pembelajaran, hasil belajar merupakan hal yang penting karena dapat menjadi petunjuk untuk mengetahui sejauh mana keberhasilan siswa dalam kegiatan belajar yang sudah dilakukan Hasil belajar dapat diketahui melalui evaluasi untuk mengukur dan menilai apakah siswa sudah menguasai ilmu yang dipelajari atas bimbingan guru sesuai dengan tujuan yang dirumuskan.

Menurut Sanjaya (2005 : 27), hasil belajar adalah gambaran kemampuan siswa dalam memenuhi suatu tahapan pencapaian pengalaman belajar dalam satu kompetensi dasar. Sehingga, untuk mencapai hasil yang diharapkan, tentu sudah selayaknya guru untuk merancang skenario pembelajaran yang bervariasi, menarik dan bermakna yang sesuai dengan semua tipe belajar siswa yang beranekaragam.

Secara garis besar faktor-faktor yang mempengaruhi hasil belajar dapat dibedakan menjadi dua jenis yaitu sebagai berikut:

a. Faktor-faktor yang bersumber dari dalam diri manusia, faktor ini dapat diklasifikasikan menjadi dua yakni faktor biologis dan faktor psikologis. Faktor biologis antara lain usia, kematangan dan kesehatan. Sedangkan faktor psikologis adalah kelelahan, suasana hati, motivasi, minat dan kebiasaan belajar.

b. Faktor-faktor yang bersumber dari luar diri manusia, faktor ini diklasifikasikan menjadi dua yakni faktor manusia dan faktor non manusia seperti alam, benda, hewan, dan lingkungan fisik (Sanjaya, 2011 : 131).

\section{METODE PENELITIAN}

Populasi dalam penelitian ini adalah siswa kelas $\mathrm{X}$ yang berjumlah 93 orang.
Berdasarkan tabel penentuan jumlah sampel dari populasi dengan tingkat kesalahan 10\% yang dikembangkan oleh Isaac dan Michel, untuk jumlah $\mathrm{n}=93$ adalah 71 orang. (Sugiyono, 2007 : 199). Sehingga sampel yang diambil dalam penelitian ini terdiri dari 18 orang untuk masing-masing kelas yaitu kelas X1, X2, X3, dan X4. Pengambilan sampel dapat digunakan teknik random sampling.

Bentuk penelitian ini adalah penelitian kuantitatif dengan pendekatan deskriptif kuantitatif yaitu studi yang bertujuan untuk mendeskripsikan atau menjelaskan suatu kejadian yang sedang berlangsung pada saat penelitian tanpa menghiraukan sebelum dan sesudahnya. (Riduwan, 2005: 207). Metode penelitian yang digunakan adalah metode korelasional. Metode Korelasional adalah penelitian yang bermaksud untuk mengetahui ada tidaknya hubungan antar dua variable (Arikunto, 2005 : 247). Untuk mencari berapa koefisien korelasi salah satu varibel bebas terhadap variable terikat ketika variable bebas lain dianggap konstan, dipergunakan persamaan korelasi pearson product moment (r). Rumus nya yaitu :

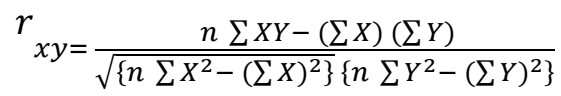

Setelah didapatkan koefisien korelasi, kemudian data tersebut diinterprestasikan berdasarkan langkah -langkah yang telah dibuat, setelah itu diambil kesimpulan yang memenuhi prasyarat ilmiah, sebagaimana tujuan penelitian ini. Dalam penelitian ini terdapat dua data yang diperlukan : yaitu Data gaya belajar siswa, data ini diungkap dengan menggunakan angket dan data hasil belajar siswa, Data ini diambil dari nilai murni semester genap tahun 2016. Sebelum angket disebarkan kepada responden, angket tersebut terlebih dahulu dilakukan uji validasi dan reliabilitas.

\section{HASIL DAN PEMBAHASAN}

Berikut hasil korelasi antara gaya belajar dengan hasil belajar siswa :

$$
r_{x y}=\frac{n \sum X Y-\left(\sum X\right)\left(\sum Y\right)}{\sqrt{\left\{n \sum X^{2}-\left(\sum X\right)^{2}\right\}}\left\{n \sum Y^{2}-\left(\sum Y\right)^{2}\right\}}
$$


$r$

$x y=\frac{71 \times 346167.5-(7772)(3157.5) \quad \text { sehari-hari, ada orang yang mudah menerima }}{\sqrt{(71 \times 853764-6040394))}(71 \times 152093.8-(996806) f m}$ $\sqrt{\{(71 \times 853764-60403984)\}}\{71$ X 152093.8- (9969806) formasi baru dengan mendengarkan langsung dari sumbernya, ada yang cukup dengan tulisan $r$ $x y=\frac{24577893-24540090}{\sqrt{\{(60617244-60403984)\}}\{10798656.25-9969806\}}$

$r_{x y=\frac{37802.5}{\sqrt{\{213260\}}\{828850\}}}$

$r_{x y=\frac{37802.5}{\sqrt{1.7676055}}}=0.08991411$

$\mathrm{R}_{\text {tabel }}=\mathrm{r}_{\mathrm{t}}=0,235$

$\mathrm{r}_{\mathrm{xy}}<\mathrm{r}_{\mathrm{t}}=0,089<0,235$

Hasil korelasi antara $r_{x y}$ dan $r_{t}$ di atas jelaslah tidak terdapat korelasi yang kuat antara gaya belajar dengan hasil belajar siswa.

Hipotesis statistik yang diuji adalah :

$\mathrm{H}_{\mathrm{a}}: \mathrm{r}=0$

$\mathrm{H}_{0}: \mathrm{r} \neq 0$

Dari hasil perhitungan diperoleh, kecilnya $r_{\text {hitung }}<r_{\text {tabel}}$, untuk semua variabel yang dikorelasikan maka hipotesis alternatif $\left(\mathrm{H}_{\mathrm{a}}\right)$ ditolak, sedangkan hipotesis nihil $\left(\mathrm{H}_{0}\right)$ diterima. Hal ini berarti kalau dilihat dari interprestasi dapat diketahui bahwa antara gaya belajar dengan hasil belajar pada pembelajaran biologi siswa kelas X di SMAN 2 Sungai tarab tidak terdapat korelasi yang signifikan.

Gaya belajar merupakan cara termudah yang dimiliki oleh individu dalam menyerap, mengatur, dan mengolah informasi yang diterima. Gaya belajar yang sesuai adalah kunci keberhasilan siswa dalam belajar.

Gaya belajar visual, auditorial, dan kinestetik merupakan suatu kombinasi dari bagaimana siswa menyerap, mengatur, dan mengolah infor masi yang pada akhirnya akan mempengaruhi prestasi belajar siswa. Hasil penelitian menunjukkan bahwa gaya belajar visual, gaya belajar auditorial, dan gaya belajar kinestetik tidak memiliki hubungan. Kecenderungan seseorang untuk belajar sangat beragam dan dipengaruhi oleh beberapa hal. Cara seseorang menyerap informasi, mengolahnya, dan memanifestasikan dalam wujud nyata perilaku hidupnya disebut dengan gaya/tipe belajar. Setiap orang memiliki gaya dan tipologi belajar yang berbeda-beda, tetapi mungkin juga ada yang memiliki gaya/tipologi belajar sejenis. Pada kenyataannya, gaya dan tipologi belajar berpengaruh terhadap hasil yang diperolehnya. Dalam realitas kehidupan atau memo, dan ada yang harus didemonstrasikan aktivitasnya. Hal tersebut menunjukkan adanya gaya/ tipe belajar pada manusia. Gaya/tipologi belajar dapat dibagi menjadi tiga. Hal ini didasarkan pada cara seseorang menyerap informasi, mengolah, dan menyampaikannya, serta secara universal atau bagaimana seseorang tersebut belajar.

Berdasarkan penjelasan sebelumnya bahwa siswa cendrung memiliki salah satu tipe/gaya belajar. Dari hasil penelitian didapatkan bahwa dari 71 orang siswa, sebagian besar siswanya memiliki gaya belajar visual dan sangat sedikit sekali yang memiliki gaya belajar kinestetik. Gaya belajar visual banyak digunakan siswa sebesar 69,01\%, gaya belajar auditorial tidak banyak digunakan siswa yaitu sebesar 25,35\%, dan gaya belajar kinestetik sangat sedikit digunakan oleh siswa sebesar 5 , $63 \%$.

Namun berdasarkan hasil korelasi yang telah dijelaskan sebelumnya, terlihat bahwa antara gaya belajar dengan hasil belajar pada pembelajaran biologi siswa tidak terdapat korelasi. Hal ini dikarenakan nilai " $\mathrm{r}_{\mathrm{xy}}$ " kecil dari $r_{\text {tabel, }}$ yaitu : 0,089<0, 235.

Berdasarkan hasil perhitungan data hubungan antara gaya belajar visual dengan hasil belajar biologi, gaya belajar auditorial dengan hasil belajar biologi, dan gaya belajar kinestetik dengan hasil belajar biologi serta gabungan gaya belajar visual, auditorial, dan kinestetik dengan hasil belajar biologi siswa kelas X SMAN 2 Sungaitarab, maka tidak terdapat hubungan yang positif dan signifikan. Berdasarkan tabel interpretasi koefisien korelasi, untuk nilai $\mathrm{r}_{\text {hitung }}=0,089$ maka tingkat hubungan korelasi antara gaya belajar dan hasil belajar biologi termasuk pada kategori sangat lemah atau sangat rendah sehingga korelasi itu diabaikan (dianggap tidak ada korelasi antara variabel $\mathrm{X}$ dan variabel $\mathrm{Y}$ ).

Pada penelitian ini ditemukan tidak terdapatnya hubungan antara gaya belajar dengan hasil belajar biologi. Hasil ini diduga disebabkan siswa tidak menerapkan gaya belajarnya masing-masing, baik itu gaya 
belajar visual, auditorial, maupun kinestetik. Karena dalam belajar dengan gaya belajar visual memiliki ciri-ciri : (1) Gunakan kertas tulis dengan tulisan berwarna, (2) Buatlah diagram, peta dan warnai untuk menggambarkan informasi yang ada, (3) Pahami konsep secara keseluruhan sebelum terjun ke bagian detailnya, (4) Berikan kode warna untuk bahan pelajaran dan perlengkapan kemudian susun pelajaran dengan aneka warna, dan (5) Gunakan simbol-simbol untuk mewakili konsep.

Sedangkan siswa yang belajar dengan gaya belajar auditorial memiliki ciriciri : (1) Gunakan variasi vokal (perubahan nada, kecepatan dan volume), (2) Gunakan pengulangan dan sebutkan kembali konsepkonsep tersebut serta kuncinya, (3) Buatlah suatu konsep menjadi nyanyian yang mudah dipahami atau dihafalkan, dan (4) Gunakan musik sebagai bagian dari kegiatan rutin anda.

Adapun siswa yang belajar dengan gaya belajar kinestetik memiliki ciri-ciri belajar: (1) Gunakan alat bantu dalam belajar untuk menimbulkan rasa ingin tahu dan untuk menekan konsepkonsep atau kunci, (2) Lakukan stimulasi konsep agar mudah dipahami, (3) Bila diberikan bimbingan oleh dosen duduklah didekatnya atau disebelahnya, (4) Peragaan konsep untuk mempelajari langkah demi langkah, dan (5) Lakukan gerakan-gerakan saat belajar untuk mempermudah mengingat (Wulandari, 2007 : 3-4)

Penyebab tidak terdapatnya korelasi gaya belajar siswa dengan hasil belajar siswa pada pembelajaran biologi dilihat dari beberapa sisi, yaitu : Guru, siswa, dan kesalahan dalam penelitian.

Pada aspek guru, guru tidak menggunakan strategi yang sesuai dengan seluruh karakteristik siswa yang beragam dikelas, hal ini disebabkan guru tidak mengikuti gaya belajar anak tersebut. Pada aspek siswa, siswa tidak menerapkan gaya belajarnya masing-masing, baik itu gaya belajar visual, auditorial, maupun kinestetik, hal ini disebabkan siswa tidak mengetahui tipe/gaya belajarnya. Sedangkan kalau dilihat dari aspek kesalahan dalam penelitian, ada beberapa kesalahan dalam penelitian ini yang menyebabkan tidak terdapatnya hubungan antara gaya belajar dengan hasil belajar siswa yaitu peneliti tidak menganalisis bagaimana cara belajar siswa dan tidak menganalisis strategi guru didalam lokal.

Selain itu peneliti melakukan uji validitas soal pada sekolah yang berbeda yang seharusnya tidak dilakukan di sekolah yang berbeda, karena hal yang ingin peneliti teliti adalah siswanya bukan gurunya.

Tidak adanya interaksi atau hubungan antara gaya belajar terhadap prestasi belajar siswa pada pembelajaran biologi dapat dikarenakan adanya faktor lain, selain gaya belajar siswa sebagai faktor internal. Faktor lain tersebut diantaranya adalah bakat, motivasi, sikap siswa, kesehatan, kondisi lingkungan kelas, dan sebagainya (Syarifuddin, dkk 2010: 43).

Gaya belajar dapat menentukan prestasi belajar anak. Jika diberikan strategi yang sesuai dengan gaya belajarnya, anak dapat berkembang dengan lebih baik (Thobroni, 2015: 219). Dari penjelasan di atas dapat disimpulkan bahwa jika tidak terdapat pengaruh atau hubungan antara gaya belajar dengan hasil belajar ada faktor lain yang mempengaruhi nya, yaitu diantaranya faktor internal siswa itu sendiri dan faktor guru yang mengajarnya dikelas, karena bisa jadi guru yang mengajar tidak memperhatikan gaya belajar anak, sehingga guru tidak memberikan strategi yang sesuai dengan gaya belajarnya, hal ini akan berdampak terhadap hasil belajar anak.

Gaya belajar memiliki pengaruh terhadap beberapa hal, diantaranya : orang dengan gaya belajar visual senang mengikuti ilustrasi, membaca instruksi, mengamati gambar-gambar, meninjau kejadian secara langsung, dan sebagainya. Hal ini sangat berpengaruh terhadap pemilihan metode dan media belajar yang dominan mengaktifkan indera penglihatan (mata). Anak yang bertipe auditorial, mudah mempelajari bahan-bahan yang disajikan dalam bentuk suara (ceramah), begitu guru menerangkan ia cepat menangkap bahan pelajaran, disamping itu kata dari teman (diskusi) atau suara radio/casette ia mudah menangkapnya. Pelajaran yang disajikan dalam 
bentuk tulisan, perabaan, gerakan-gerakan maka ia akan mengalami kesulitan dalam belajar. gaya belajar kinestetik memperoleh informasi dengan mengutamakan indera perasa dan gerakan-gerakan fisik. Individu yang bertipe ini, mudah mempelajari bahan yang berupa tulisan-tulisan, gerakan-gerakan, dan sulit mempelajari bahan yang berupa suara atau penglihatan. Semua hal di atas dapat mempengaruhi hasil belajar siswa.

Ada beberapa cara atau strategi yang dapat digunakan oleh guru untuk mempermudah proses belajar anak agar anak memiliki hasil belajar yang baik, yaitu : (1) Visual : Cara membuat anak yang gaya belajarnya visual mudah memahami pelajaran yaitu : menggunaka materi visual seperti gambar-gambar, diagram dan peta serta berwarna agar anak merasa tertarik untuk belajar, (2) Auditorial : Anak yang belajar dengan gaya belajar auditorial dapat diajak untuk ikut berpartisipasi dalam diskusi, baik di dalam kelas maupun di dalam keluarga, atau bisa menggunakan musik dalam proses pembelajaran, dan (3) Kinestetik : Anak yang gaya belajar kinestetik, ajak anak untuk belajar sambil mengeksplorasikan lingkungannya, atau mengizinkannya mengunyah permen karet pada waktu PBM berlangsung.

Hal di atas dapat dilakukan oleh guru maupun orang tua dirumah agar anak merasa nyaman belajar dan mendapatkan hasil belajar yang maksimal.

Hasil uji statistik menunjukkan bahwa gaya belajar tidak berpengaruh terhadap hasil belajar biologi siswa. Temuan ini tidak sejalan dengan kajian psikologi belajar dan temuan peneliti mira wulandari yang melaporkan bahwa Terdapat hubungan yang positif antara gaya belajar dengan hasil belajar siswa kelas XI MIA di SMA Negeri I Kota Jambi. Namun, temuan penelitian lain menyatakan bahwa tidak adanya pengaruh gaya belajar siswa terhadap hasil belajar diduga karena: batas gaya belajar yang dimiliki siswa kurang tegas. Siswa bergaya belajar visual, memiliki unsur-unsur gaya belajar auditori maupun kinentetik. Siswa bergaya belajar auditori, memiliki unsur-unsur gaya belajar visual maupun kinestetik demikian pula dengan siswa yang bergaya belajar kinestetik, ternyata juga memiliki unsur-unsur gaya belajar visual dan auditori (Purwoko, 2014: 4). Peneliti lain juga mendukung penelitian ini yaitu tidak terdapat pengaruh yang signifikan gaya belajar terhadap kemampuan berpikir kritik biologi (Harie, 2015 :10)

Adapun keterbatasan dalam penelitian ini adalah seharusnya penelitian ini menggunakan analisis jalur, sedangkan pada penelitian ini tidak menggunakan analisis jalur. Jadi, untuk penelitian berikutnya dapat menggunakan analisis jalur agar hasil yang didapat lebih jelas.

Penelitian ini adalah penelitian Ex Post Facto, yaitu penelitian yang dilakukan apabila perlakuan atau manipulasi variabel tertentu telah terjadi sebelumnya, sehingga tidak perlu diberikan perlakuan lagi pada variabel tersebut. Hal inilah salah satu kelemahan dari penelitian ex post facto, sehingga apapun hasil dari penelitian ini tidak perlu diberikan perlakuan lagi terhadap variabelnya. Sehingga hasil dari penelitian ini tidak mendukung hipotesis peneliti.

\section{KESIMPULAN}

Berdasarkan permasalahan yang diungkapkan dan analisis data, maka kesimpulan dari penelitian ini adalah berdasarkan uji signifikan bahwa tidak terdapat hubungan yang signifikan antara gaya belajar siswa dengan hasil belajar siswa kelas $\mathrm{X}$ SMAN 2 Sungaitarab baik itu hubungan secara terpisah untuk setiap gaya belajar maupun hubungan secara bersama-sama.

\section{DAFTAR KEPUSTAKAAN}

Arikunto S. 2005. ManajemenPenelitian. Jakarta: PT RinekaCipta.

Harie S. 2015. Pengaruh Metode Pembelajaran Dan Gaya Belajar Terhadap Kemampuan Berpikir Kritik Biologi. Jurnal Formatif 5(3): 257-267

Hasrul. 2009. Pemahaman Tentang Gaya Belajar. jurnal Medtek. Vol. 1No.2 : 1-9

Irham M dan Wiyani NA. 2014. Psikologi Pendidikan Teori dan Aplikasi dalam 
Proses Pembelajaran. Yogyakarta: ArRuzz Media.

Liyusri dan Julaga S. 2013 . Strategi Pembelajaran Dan Gaya Belajar Terhadap Hasil Belajar Geografi. Jurnal Teknologi Pendidikan. Vol.6 No 1 : 1-15.

Purwoko S. 2014. Pengaruh Penggunaan Peta Pikiran dan Gaya Belajar terhadap Hasil Belajar Geografi Siswa SMP. Jurnal Pendidikan Humaniora, Vol. 2 No. $2: 1$ 5

Rahmawati, Ira TT. Pengaruh Gaya Belajar Bahasa Terhadap Prestasi Belajar Bahasa Arab Kelas VII Semester II di MTsN Galur. Skripsi Sarjana Pendidikan Bahasa Arab Fakultas Tarbiyah dan Keguruan Universitas Islam Negeri Sunan Kalijaga.

Riduwan. 2005. Belajar Mudah Penelitian untuk Guru-Karyawan Dan Peneliti Pemula. Bandung: Alfabeta.

Sanjaya W. 2005. Pembelajaran dalam mplementasi Kurikulum Berbasis Kompetensi. Bandung : Kencana Prenada Media Group.
Sanjaya W .2011. Perencanaan dan Desain Sistem Pembelajaran. Jakarta: Kencana Prenada Media Group.Sopiatin P dan Sahrani S. 2011.Psikologi Belajar dalam Perspektif Islam. Bogor :Ghalia Indonesia.

Sugiyono. 2007. Metode Penelitian Pendidikan Pendekatan Kuantitatif, Kualitatif, dan $R \& D$. Bandung: Alfabeta.

Syarifuddin, dkk. 2010. Strategi Belajar Mengajar. Jakarta : Diadit Media

udjana N. 2005. Penilain Hasil Proses Belajar Mengajar. Bandung: PT Remaja Rosdakarya.

Thobroni. 2015. Belajar Dan Pembelajaran. Yogyakarta : Ar-Ruzz Media.

Wiyani NA. 2013. Manajemen Kelas Teori dan Aplikasi untuk Menciptakan Kelas yang Kondusif. Yogyakarta :Ar-Ruzz Media.

Wulandari R. 2007. Hubungan Gaya Belajar dengan Pestasi Belajar Mahasiswa Semester IV Program Study D IV Kebidanan Universitas Sebelas Maret. Jurnal ResMaDaSka. Vol. 2 No 1: 1-8. 